九州大学学術情報リポジトリ

Kyushu University Institutional Repository

\title{
Study on Deorbit of a Microsatellite Considering the Solar Activity Effect on Atmospheric Density
}

\section{片山，雅之}

三菱プレシジョン株式会社鎌倉事業所

HOKAMOTO, Shinji

Department of Aeronautics and Astronautics, Kyushu University

麻生，茂

久留米工業大学工学部交通機械工学科

平山，寛

秋田大学理工学部システムデザインエ学科

ht tp://hdl. hand le. net/2324/4479600

出版情報: AEROSPACE TECHNOLOGY JAPAN, THE JAPAN SOCIETY FOR AERONAUTICAL AND SPACE SCIENCES. 19, pp.47-55, 2020-03-14. The Japan Society for Aeronautical and Space Sciences バージョン :

権利関係: (c) 2020 The Japan Society for Aeronautical and Space Sciences 


\title{
太陽活動による大気密度の変化を考慮した小型衛星のデオービット に関する考察*1
}

\section{Study on Deorbit of a Microsatellite Considering the Solar Activity Effect on Atmospheric Density}

\author{
片山雅 之块*3 外本伸 治*3 - 麻生 茂*4 -平山寛 ${ }^{* 5}$ \\ Masayuki Katayama, Shinji Hokamoto, Shigeru Aso and Hiroshi Hirayama
}

Key Words: Satellite, Orbital Mechanics, Deorbit, Aerodynamic Drag, Solar Activity

\begin{abstract}
The effect of aerodynamic drag on loss of the velocity of a microsatellite on LEO is investigated and compared with the on-orbit data of two microsatellites, Hodoyoshi-1 of the University of Tokyo and QSAT-EOS of Kyushu University, which were launched in 2014. A new model, which includes the influence of the solar activities on atmospheric density, is introduced in this paper. The results obtained from the model suggest that the effect of solar activity on the atmospheric density has to be considered with the deviation of F10.7 parameter due to the number of sunspots. The model is applied to a microsatellite composed of a cubic main body and a deorbit sail to estimate its altitude change due to aerodynamic drag. The rotation of the satellite is taken into consideration.
\end{abstract}

\section{記 号の 説 明}

$\vec{r}: \quad$ 軌道上衛星位置ベクトル

$r$ : 衛星質量中心と地球質量中心の距離 $(r=|\vec{r}|)$

$\vec{p}: \quad$ 衛星に㗢く摂動加速度ベクトル

$\vec{v}_{r e l}$ : 衛星の大気に対する相対速度ベクトル

$\mu$ : 地球重力定数

$C_{D}$ : 衛星の空気抵抗係数

$\rho$ : 大気密度

$A$ : 代表面積

$m:$ 衛星質量

$B:$ 弾道係数 $\left(=C_{D} \cdot A / m\right)$

\section{1. 序}

論

近年，超小型衛星の利用が進んでおり，運用を終了した 大量の小型衛星が軌道上にデブリとして残存するという課 題が問題視されている.このため, IADC(Inter-Agency Space Debris Coordination Committee) は，低高度軌道で運用され る衛星の軌道上残存寿命を 25 年以下とするように提言し ている 1). デオービットの方法としては，スラスタによる 減速, 導電性テザーに働くローレンツ力を利用する方法, 空気抵抗を利用した減速等が提案されている．代表的なデ オービットの方式の比較を第 1 表に示す. しかし, 今後益々 打ち上げが増加すると予想される超小型衛星の場合, ペイ ロードスペースが限られており，デオービットのためのス

\footnotetext{
*1 C2020 日本航空宇宙学会

2019 年 6 月 24 日原稿受付

*2 三菱プレシジョン株式会社 鎌倉事業所

*3 九州大学大学院 工学研究院

*4 久留米工業大学 工学部 交通機械工学科

*5 秋田大学 理工学部システムデザイン工学科
}

ラスタ及び推進薬や導電性テザー及びそれに付随するデバ イスを搭載することは好ましくない。一方，空気抵抗によ る減速は, ペイロードペナルティが少ないため, 超小型衛 星にも有望な方法である. 超小型衛星が多く投入される軌 道高度 $500 \mathrm{~km}$ 程度であれば, IADC が推奨する 25 年ルール を満たすが，更に高い高度からのデオービットには，空気 抵抗を増加させて再突入までの期間を短縮し, 25 年ルール を確実に満たすことが必要となる．空気抵抗を増加させる 機構として，膨張気球，薄膜セイル等があるが，超小型衛 星には，気球膨張のためのガス発生源や複雑な調圧機構を 必要とせず，機械的な機構のみで展開できる薄膜セイルが 有利であると考えられる。

第 1 表 デオービット方式の比較

\begin{tabular}{|c|c|c|}
\hline 方 式 & 利 点 & 欠 点 \\
\hline スラスタ 2) & $\begin{array}{l}\text { (1)化学推進 : 必要な減速量 } \\
\text { を短時間に得られる } \\
\text { (2)電気推進 : 必要な推進薬 } \\
\text { 質量が少ない }\end{array}$ & $\begin{array}{l}\text { (1)推進薬質量がペイロ } \\
\text { ードペナルティとなる } \\
\text { (2)長期間にわたる姿勢 } \\
\text { 制御及び電力の確保が } \\
\text { 課題である }\end{array}$ \\
\hline 導電性テザー3,4) & $\begin{array}{l}\text { ·誘起起電力が得られるの } \\
\text { でエネルギーが不要である }\end{array}$ & $\begin{array}{l}\text { テザー展張機構等によ } \\
\text { り複雑になる } \\
\text { また, テザー制御等が } \\
\text { 課題である }\end{array}$ \\
\hline 薄膜セイル 5) & $\begin{array}{l}\text { •大気抵抗によるため, エネ } \\
\text { ルギーを必要としない } \\
\text { •比較的簡便で軽量である }\end{array}$ & $\begin{array}{l}\text { セイル展開機構が必要 } \\
\text { である }\end{array}$ \\
\hline
\end{tabular}

運用終了後の超小型衛星のデブリ化を防ぐために，超小 型衛星で通常良く用いられる高度 500〜 1000km における 軌道上寿命の推定，デオービット方式による軌道高度低下 率の変化の推定は，超小型衛星の運用における重要な検討 
項目である. 軌道離脱後の衛星の高度変化を予測する研究 は多くなされており，NASA が開発したDebris Assessment Software ${ }^{6)}$, JAXA が開発したデブリ発生防止標準支援シス テム(Debris Mitigation Standard Support Tools : DEMIST)等 のツールがある.これらは優れたツールであるが，モデル の詳細は公開されておらず, 第 3 者による改善・高精度化 は難しい.

本論文では, 空気抵抗による衛星軌道高度変化において, 太陽活動が大気密度に与える影響の重要性を示すそそのた めに, 2014 年 11 月に打ち上げられた超小型衛星「ほどよ し 1 号」及び「QSAT-EOS」の軌道高度データを用い，そ の影響を定量的に分析した.さらに，デオービットセイル を有する超小型衛星の力学モデルを提案し, デオービット セイル展開後の軌道高度の変化を解析するシミュレーショ ン結果を報告する，特に，太陽活動が大気密度に与える影 響, デオービットセイルを展開した形態の衛星の抵抗係数 について, シミュレーションの結果と軌道データの比較に より考察する.

\section{2. 軌 道 解 析}

2.1 摂動要因を考慮した運動方程式 地球の軌道を周 回する人工衛星には, 空気抵抗の他, 地球重力ポテンシャ ル, 太陽及び月の引力等, 種々の外力による攝動加速度が 生じるが，軌道高度に大きな影響を与える加速度は空気抵 抗による減速加速度である。これは空気抵抗が常に減速方 向に作用するのに対して, 空気抵抗以外の要因による加速 度は, 軌道上の位置に応じて加減速として作用し, 減速効 果が相殺されるためである. 外力加速度を考慮した人工衛 星の運動方程式は，式(1)で与えられる ${ }^{7)}$.

$$
\ddot{\vec{r}}=-\frac{\mu}{r^{3}} \cdot \vec{r}+\vec{p}
$$

式(1)の摂動加速度が空気抵抗による加速度のみである とすれば，摂動加速度は式(2)で与えられる。

$$
\vec{p}=-\frac{1}{2} \rho \cdot\left|\vec{v}_{r e l}\right| \cdot B \cdot \vec{v}_{r e l}
$$

ここで, | |はベクトルの絶対值を示す.

2.2 軌道データ 2014 年 11 月 6 日に打ち上げられた超 小型衛星，「ほどよし 1 号」と「QSAT-EOS」の軌道投入 直後から, 2017 年 2 月 6 日までの半長径の推移を第 1 図に 示す.このデータは米国の JSpOC(Joint Space Operations Center: 現在の CSpOC(Combined Space Operations Center), 2018 年 7 月に改編)が検出・追跡・識別し, 公開されてい る值である.

2 つの衛星は, 第 2 表に示すとおり, ほぼ同等の物理諸 元を有しているが,「ほどよし 1 号」と比べ,「QSAT-EOS」 は高度の低下が大きいことが分かる。「QSAT-EOS」はデ オービットセイルを搭載しており, 運用終了後に展開して 運用軌道を離脱, 再突入する計画になっていた。運用軌道 投入後の軌道高度の低下が大きいことから,「QSAT-EOS」
は運用軌道投入直後から意図せず，デオービットセイルが 展開した可能性があると推察される.

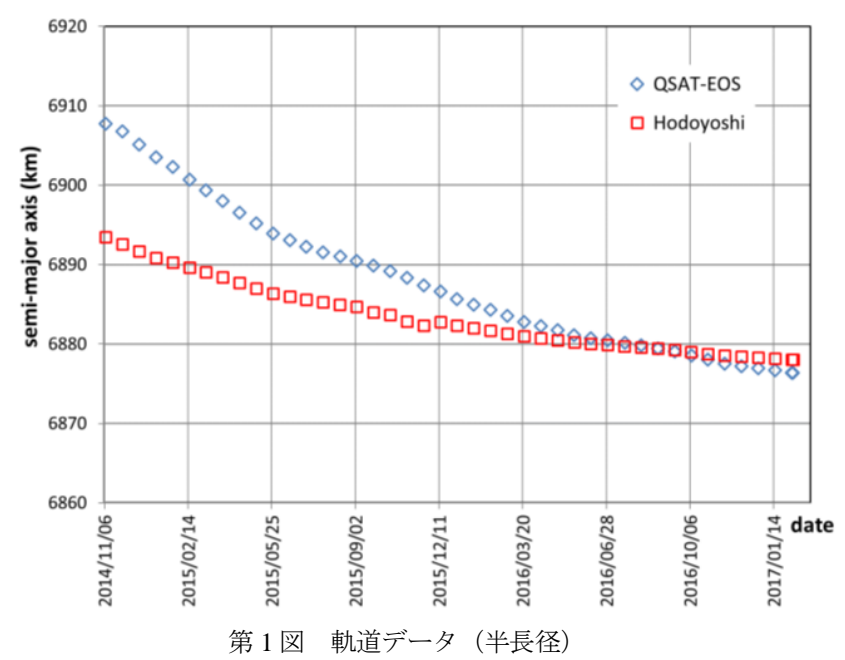

\begin{tabular}{|c|c|c|}
\hline 項 目 & ほどよし 1 号 & QSAT-EOS \\
\hline 寸 法 & $50 \times 50 \times 50 \mathrm{~cm}$ & $\begin{array}{c}50 \times 50 \times 50 \mathrm{~cm} \\
(\text { 運用時 }) \\
50 \times 50 \times 350 \mathrm{~cm} \\
\text { (デオービットセイル展開時) }\end{array}$ \\
\hline 質 量 & $60 \mathrm{~kg}$ & $50 \mathrm{~kg}$ \\
\hline
\end{tabular}

第 2 表「ほどよし 1 号」と「QSAT-EOS」の概要（物理諸元）

\section{3 解析結果（「ほどよし 1 号」）}

(1) シミュレーション条件「ほどよし 1 号」の軌道シ ミュレーションは 2.1 節で示した運動方程式により, 第 3 表に示す条件で実施した. なお，第 1 図の「ほどよし 1 号」 の 2015 年 10 月〜 12 月のデータにある不連続点は軌道制御 を行ったことによるものであるため, 軌道制御前後の $2 つ$ の区間に対して解析した。 区間(1) 2014 年 11 月 6 日を起 点とした 320 日間, 区間(2)は 2015 年 12 月 31 日を起点とし た 400 日間である.

\begin{tabular}{|c|c|c|}
\hline 項 目 & 諸 元 & 備 考 \\
\hline $\begin{array}{c}\text { 軌道要素 } \\
\text { 区間1 } \\
\text { 初期値 }\end{array}$ & $\begin{array}{l}\mathrm{a}(\text { 半長径 })=6893.5 \mathrm{~km} \\
\mathrm{e}(\text { 離心率 })=0.001328 \\
\mathrm{i}(\text { 傾斜角 })=97.48^{\circ} \\
\Omega(\text { 升交点 })=29.94^{\circ} \\
\omega(\text { 近心点引数 })=184.61^{\circ} \\
\theta(\text { 真近点離角 })=175.60^{\circ}\end{array}$ & $\begin{array}{l}2014 \text { 年 } 11 \text { 月 } 6 \text { 日 11:50(UTC) } \\
\text { の値 }\end{array}$ \\
\hline $\begin{array}{c}\text { 軌道要素 } \\
\text { 区間(2) } \\
\text { 初期值 }\end{array}$ & $\begin{array}{l}\mathrm{a}(\text { 半長径 })=6882.4 \mathrm{~km} \\
\mathrm{e} \text { (離心率 })=0.001440 \\
\mathrm{i}(\text { 傾斜角 })=97.44^{\circ} \\
\Omega(\text { 昇交点 })=84.32^{\circ} \\
\omega(\text { 近心点引数 })=157.29^{\circ} \\
\theta(\text { 真近点離角 })=267.71^{\circ}\end{array}$ & $\begin{array}{l}2015 \text { 年 } 12 \text { 月 } 31 \text { 日 } 05: 55(\mathrm{UTC}) \\
\text { の值 }\end{array}$ \\
\hline 抵抗係数 & 2.5 & 文献 8)の推奨值 \\
\hline 代表面積 & $0.25 \mathrm{~m}^{2}$ & $\begin{array}{l}1 \text { 辺 } 50 \mathrm{~cm} \text { の立方体の } \\
\text { 正面面積 }(*)\end{array}$ \\
\hline
\end{tabular}

第 3 表「ほどよし 1 号」シミュレーション条件

(*) 衛星は初期の姿勢安定化（デタンブリング）を完了し, 衛星正面が 飛行方向に正対しているとした. 
（2）シミュレーション結果

式(1)及び(2)を用いて，第 3 表の条件で実施した「ほどよ し 1 号」の解析結果を第 2 図に示寸. 第 2 図(a)は区閒(1), 第 2 図(b)は区間(2)の結果である.シミュレーションでは, 式(2)の大気密度 $\rho$ USSA76 ${ }^{9)}$ の大気モデルを用いた. なお，第 2 図の時間軸は区間(1)の開始時点 (2014 年 11 月 6 日）基準としている.

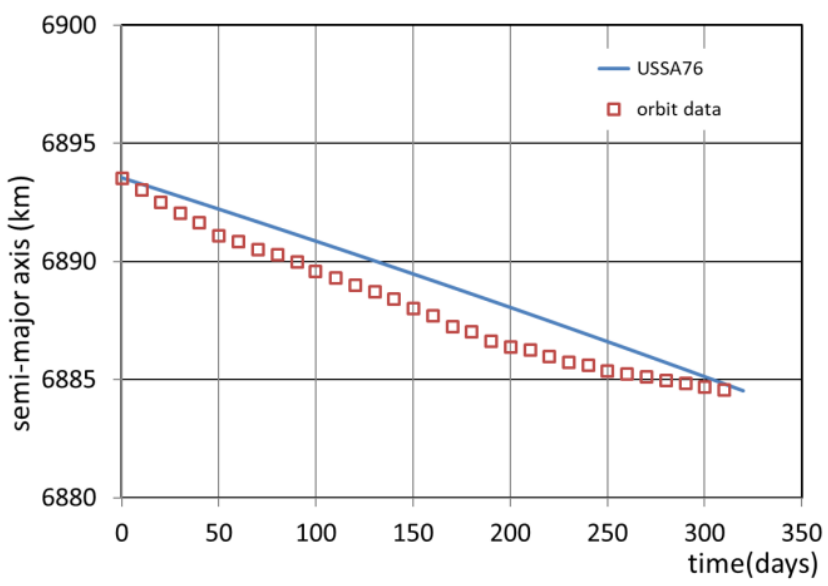

第 2 図(a) 半長径の軌道データと解析の比較

「ほどよし 1 号」 2014 年 11 月 6 日から 320 日間

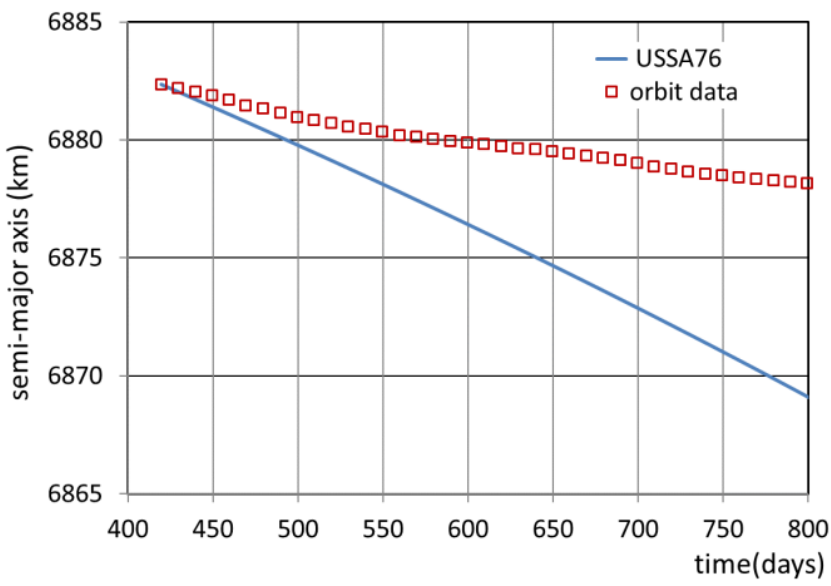

第 2 図(b) 半長径の軌道データと解析の比較

「ほどよし 1 号」 2015 年 12 月 31 日から 400 日間

区間(1)の 320 日間の軌道高度低下量は軌道データ及び解 析共に約 $8.5 \mathrm{~km}$ であり，概小一致しているが，高度変化の 傾向は, 解析が直線的であるのに対して, 軌道データは曲 線的であるという違いがある。また，区間(2)の 400 日間の 軌道高度低下量は解析では約 $14 \mathrm{~km}$ であるが，軌道データ は約 $4.3 \mathrm{~km}$ であり，違いが大きい.

これは，大気モデル USSA76 が太陽活動の大気密度に対 する影響を考慮していない静的なモデルであるためであり， その使用限界については, Oltrogge らが文献 10)で指摘して いる.

一方，太陽活動が大気密度に及ぼす影響については，い くつかの研究があるが，以下では太陽活動を代表する太陽
黒点数と波長 $10.7 \mathrm{~cm}$ の電波フラックス（F10.7 值）及び大 気密度の関係を比較的簡便に, かつ直接的に表わす文献 11) のモデル(以下 Wertz のモデルという)を用いて解析する。

\section{3. 太陽活動の影響を考慮した軌道解析}

衛星の軌道高度を低下させる大気の抵抗は，大気密度に 大きく影響されるが，大気密度は太陽活動によって変化す ることが知られている．太陽活動を表す指標である F10.7 值の観測值は，The Center for Space Standards \& Innovation (CSSI)が提供している HP, CelesTrack の Space Weather Data Documentation $^{12)}$ により得ることができる. 2014 年初から 2018 年末までのデータを第 3 図に示寸. 第 3 図より, F10.7 值は短期間に大きく変動していることが分かる.

一方，1930 年から現在までの太陽黒点数の推移と標準偏 差は第 4 図に示すとおりであり，11 年の周期で変化してい ることが分かる.

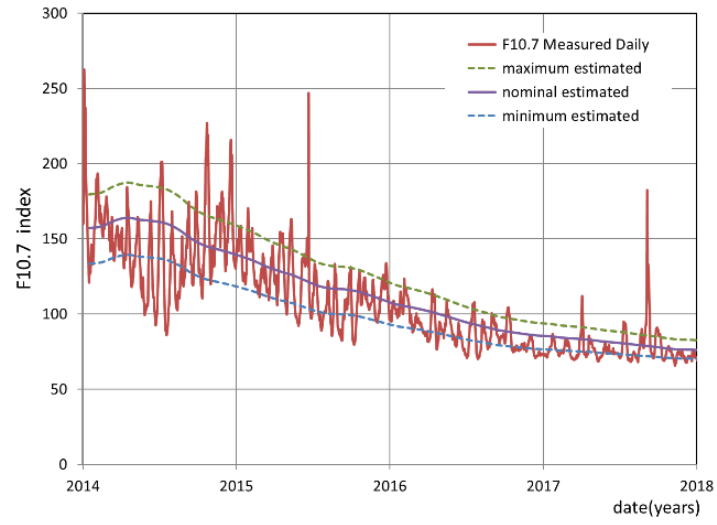

第 3 図 F10.7 值の変化（2014 年 1 月から 2018 年 12 月） 12
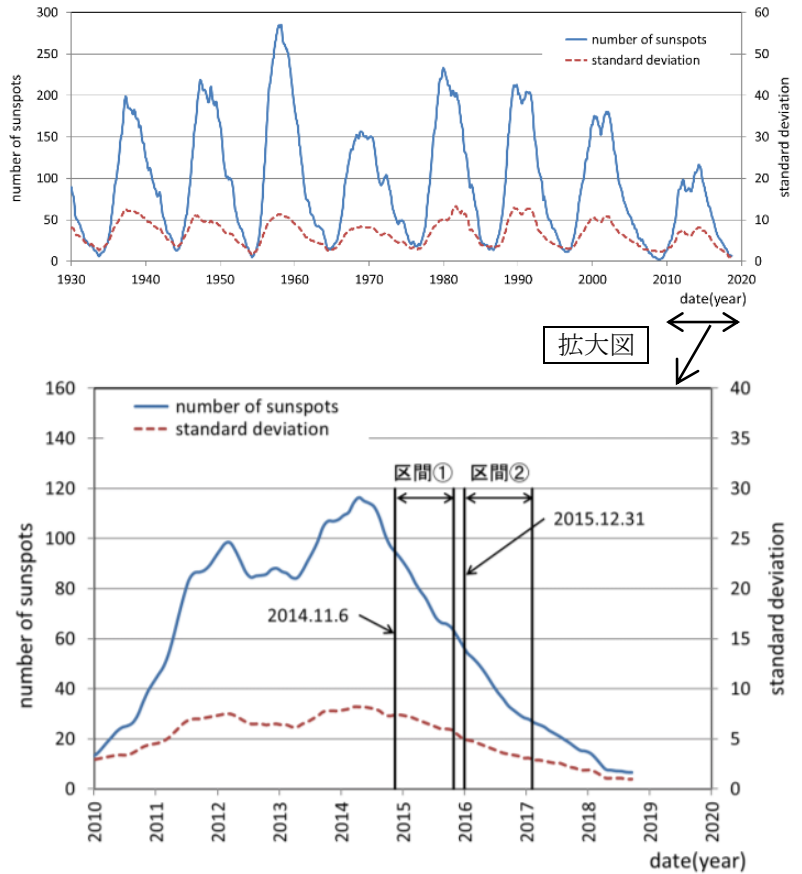

第 4 図 太陽黒点数の推移（1930 年〜現在） ${ }^{13}$ ) 
太陽黒点数と F10.7 值のデータを統計的に処理し, その 関係を整理したものが，第 5 図である. 第 5 図は 1947 年か ら 1990 年の間の太陽黒点数と F10.7 值の観測值の月毎平均 值を示すが, 両者の関係には変動があり, 最大值, 平均值, 最小值は，それぞれ式(3)，(4)，(5)で近似される，なお，最 大值及び最小值に対する近似式は，筆者が多項式近似によ り求めた。

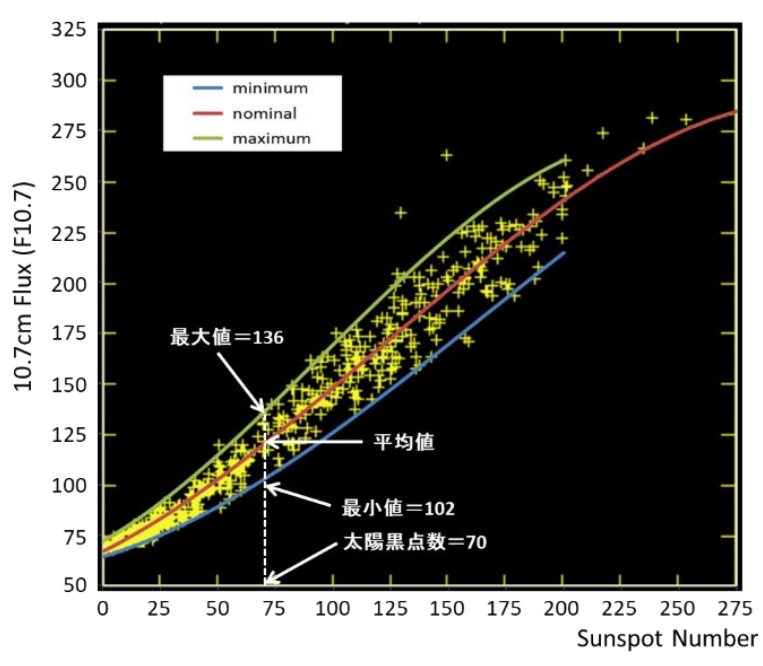

第 5 図太陽黒点数と F10.7 值の関係 ${ }^{14}$

$<$ 最大值 $>$

$\mathrm{F} 10.7_{\text {max }}=72.1+0.646 R+(0.0710 R)^{2}-(0.0261 R)^{3}$ $<$ 平均值 $>$

$\mathrm{F} 10.7$ ave $=67.0+0.572 R+(0.0575 R)^{2}-(0.0209 R)^{3}$

$<$ 最小值 $>$

$\mathrm{F} 10.7_{\text {min }}=64.4+0.342 R+(0.0584 R)^{2}-(0.0190 R)^{3}$

ここで，第 4 図の太陽黒点数を使って，第 5 図の関係か ら F10.7 值を推定した結果を第 3 図に重ねて示寸。第 5 図 の関係を使うことで, F10.7 值の大きな変動が平滑化され, 計測值の変動範囲を概ね良く表していることが分かる.

文献 11)は，第 6 図に示すとおり，高度に対する大気密 度の変化を F10.7 值のパラメータとして与えている.

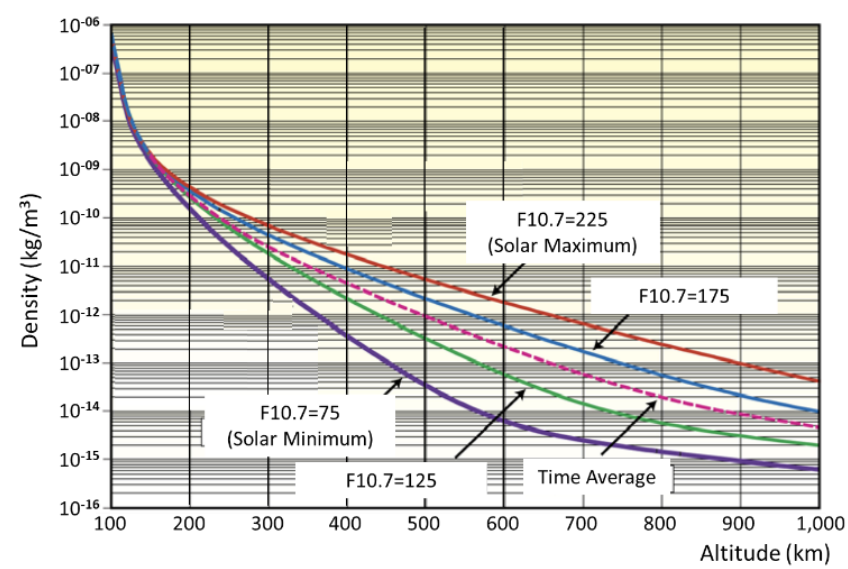

第 6 図 F10.7 值毎の高度と大気密度の関係 ${ }^{11)}$
2.3 節(2)で解析した「ほじよし 1 号」に対しては，第 4 図より, 区間(1)の黒点数は約 95〜65 個 (標準偏差 7〜6個), 区間(2)の黒点数は約 55〜27 個（標準偏差 5〜3 個）で変動 している.さらに, 第 5 図に示されるとおり, 黒点数と F10.7 值の関係にも変動幅があり，例えば区間(1)内の中間期にお いて黒点数を 70 としても，F10.7 值の最大值と最小值の変 動は 34 程度ある．従って，この時期の「ほどよし 1 号」の 軌道高度が約 $500 \mathrm{~km}$ であることを考えると，第 6 図から得 られる大気密度は，区間(1)で $3.4 \times 10^{-14} \sim 3.5 \times 10^{-13} \mathrm{~kg} / \mathrm{m}^{3}$, 区間(2)で $9.5 \times 10^{-14} \sim 2.2 \times 10^{-12} \mathrm{~kg} / \mathrm{m}^{3}$ 程度の幅があると考え られる.従って,第 6 図を用いて大気密度を推定する場合, F10.7 值の変動を考慮しなければならないことが分かる.

この変動を考慮して「ほじよし 1 号」の軌道を解析した。 解析手順を第 7 図に，解析の結果を第 8 図に示寸。解析は 2.3(2)節と同様，2つの区間に対して実施し，第 8 図の時間 軸は区間1)の開始時点（2014 年 11 月 7 日）を基準として いる。まず，第 4 図の太陽黒点数の平均值で第 5 図より推 定した F10.7 值の平均值((4)式)で第 6 図より得られる大気 密度を用いた結果を'Average'，太陽黒点数の最大值で推定 した F10.7 值の最大值((3)式)で得られる大気密度を用いた 結果を'Maximum'で示す。さらに，平均值の大気密度に対 して修正係数を適用し，それぞれの区間で軌道データに最 も良く一致するものを求めた。その結果，区間(1)では修正 係数 1.9, 区間(2)では修正係数 2.8 の場合に軌道上データと 近い結果が得られた。

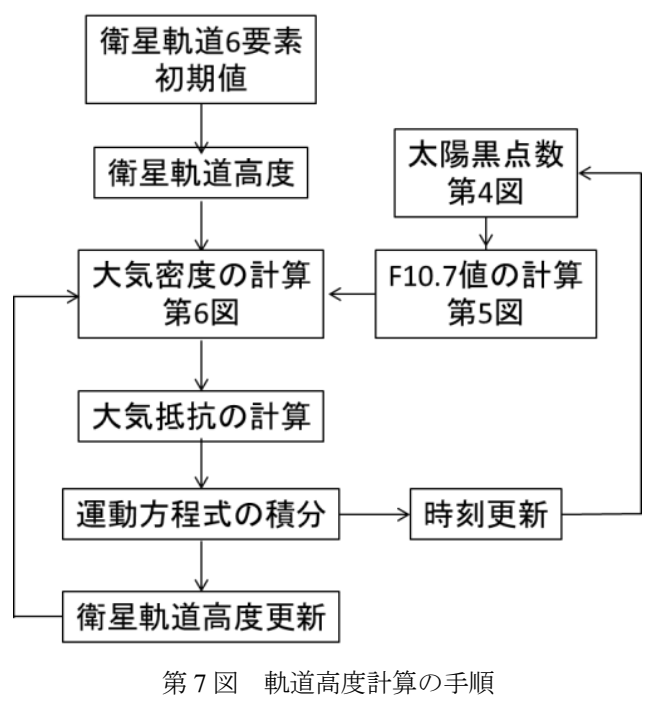




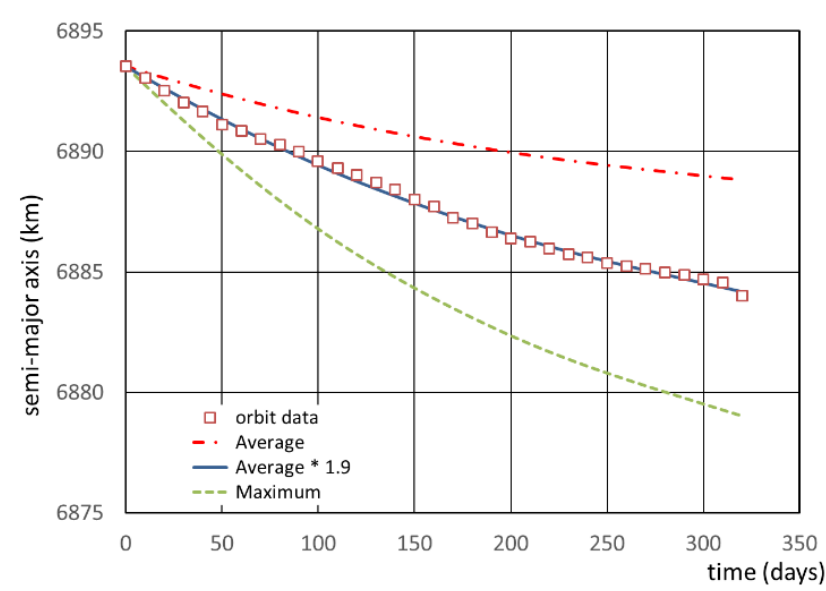

第 8 図(a) 半長径の変化（シミュレーション結果）

「ほよ゙よし 1 号」(区間1 : 2014 年 11 月 6 日から 320 日間)

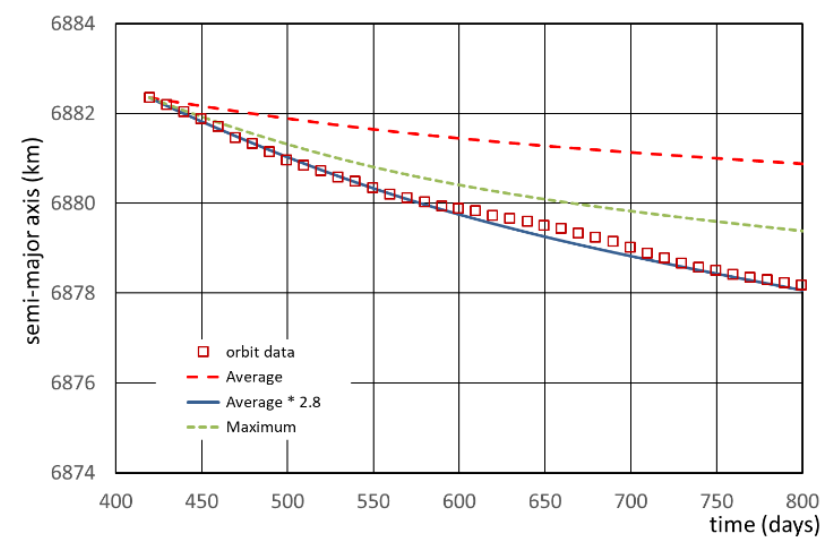

第 8 図(b) 半長径の変化（シミュレーション結果）

「ほどよし 1 号」(区間(2)：2015 年 12 月 31 日から 400 日間)

以上のとおり, Wertz のモデルは太陽活動の大気密度に 対する影響を考慮しているが，F10.7 值と太陽黒点数の関 係には変動幅があり，実際の大気密度を推定するために， 修正係数を用いることが必要である。 区間(1)の修正係数

（1.9）は，Wertzのモデルの平均值と最大值の間に入って いるが，区閒(2)の修正係数（2.8）は，最大值の範囲を超え る結果になっている．従って，太陽活動が弱い場合 (F10.7 值が 100 以下）のモデルの精度については, 改善が必要で あると考えられる。

本論文で示した太陽黒点数から大気密度を推定する手法 では，太陽黒点数の周期性から，設計時においても将来の 大気密度を推定しやすいという利点がある。ただし，推定 される F10.7 值には幅があり，上下限幅及び修正係数を適 切に決定する手法については，実軌道データを用いた更な る研究の余地がある。

\section{QSAT-EOS のデオービットセイルに対する解析}

4. 1 シミュレーション条件「ほどよし 1 号」の解析結 果（大気密度の修正係数）を用いて，「QSAT-EOS」の軌 道を検討する，前述のとおり，「QSAT-EOS」の高度低下
は，同等の物理諸元を有する「ほどよし 1 号」に比べて大 きいため, デオービットセイルが部分的に展開している可 能性がある。そこで，ここでは軌道データとの整合性から 逆にデオービットセイルの展開量の推定を試みる.

「QSAT-EOS」の物理諸元は第 2 表に示すとおりであり, 軌道シミュレーションは第 4 表に示す条件で実施した。

第 4 表「QSAT-EOS」シミュレーション条件

\begin{tabular}{|c|c|c|}
\hline 項 目 & 諸 元 & 備 考 \\
\hline $\begin{array}{l}\text { 軌道要素 } \\
\text { 区間 } 11 \\
\text { 初期值 }\end{array}$ & $\begin{array}{l}\mathrm{a}(\text { 半長径 })=6907.7 \mathrm{~km} \\
\mathrm{e}(\text { 離心率 })=0.003834 \\
\mathrm{i}(\text { 傾斜角 })=97.48^{\circ} \\
\Omega(\text { 昇交点 })=29.95^{\circ} \\
\omega(\text { 近心点引数 })=180.98^{\circ} \\
\theta \text { (真近点離角 })=180.64^{\circ}\end{array}$ & $\begin{array}{l}2014 \text { 年 } 11 \text { 月 } 6 \text { 日 11:51(UTC) } \\
\text { の值 }\end{array}$ \\
\hline $\begin{array}{l}\text { 軌道要素 } \\
\text { 区間(2) } \\
\text { 初期值 }\end{array}$ & $\begin{array}{l}\mathrm{a}(\text { 半長径 })=6885.7 \mathrm{~km} \\
\mathrm{e}(\text { 離心率 })=0.003059 \\
\mathrm{i}(\text { 傾斜角 })=97.44^{\circ} \\
\Omega(\text { 升交点 })=82.21^{\circ} \\
\omega(\text { 近心点引数 })=166.19^{\circ} \\
\theta \text { (真近点離角 })=278.56^{\circ}\end{array}$ & $\begin{array}{l}2015 \text { 年 } 12 \text { 月 } 31 \text { 日 } 05: 09 \text { (UTC) } \\
\text { の值 }\end{array}$ \\
\hline 抵抗係数 & $\begin{array}{c}2.5 \text { (衛星本体) } \\
\left.1.28^{(*)} \text { (セイル : 気流垂直 }\right) \\
\left.0.001^{(*)} \text { (セイル : 気流平行 }\right)\end{array}$ & $\begin{array}{l}(*) \text { 文献 } 15) \\
(* *) \text { 文献 16) }\end{array}$ \\
\hline 代表面積 & $0.25 \mathrm{~m}^{2}$ & 1 辺 $50 \mathrm{~cm}$ の立方体の正面面積 \\
\hline
\end{tabular}

4. 2 デオービットセイルモデル デオービットセイルの 概要を第 9 図に，展開時のイメージを第 10 図に示す.
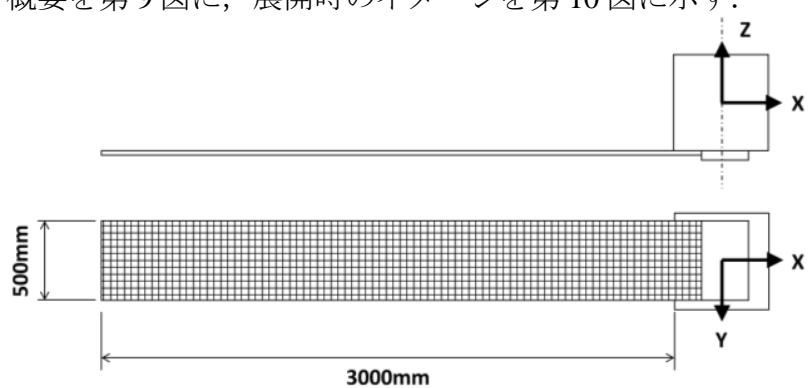

第 9 図 デオービットセイルの概要（形状寸法）

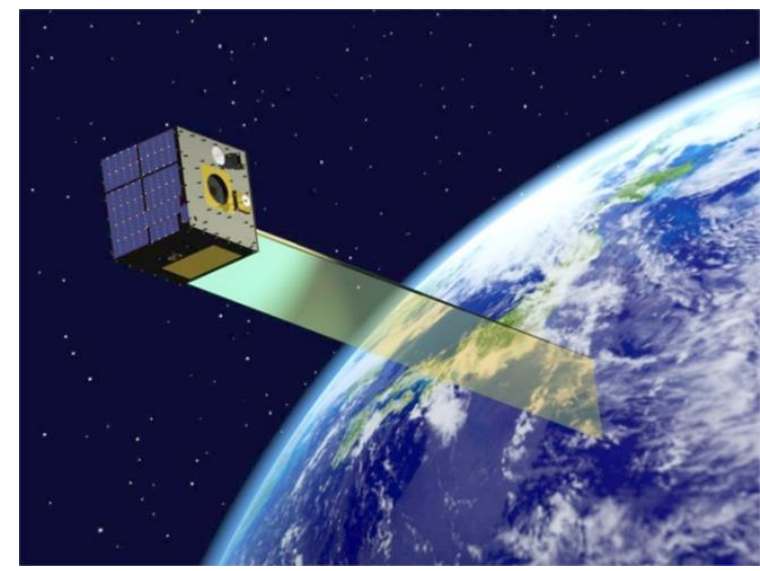

第 10 図 デオービットセイルの概要（展開時イメージ）

デオービットセイル展開時の衛星の空気抵抗モデルを下 記のとおり設定した. デオービットセイル展開後の衛星は 
衛星本体（1 辺が $0.5 \mathrm{~m}$ の立方体）とデオービットセイル $(0.5 \mathrm{~m} \times$ 展開量 $(\mathrm{m})$ の平板）からなるとし, 衛星機体軸 の各軸に対する相対速度から空気抵抗モデルを構築した.

第 11 図には, 衛星モデルと空気との相対速度の関係を示す.

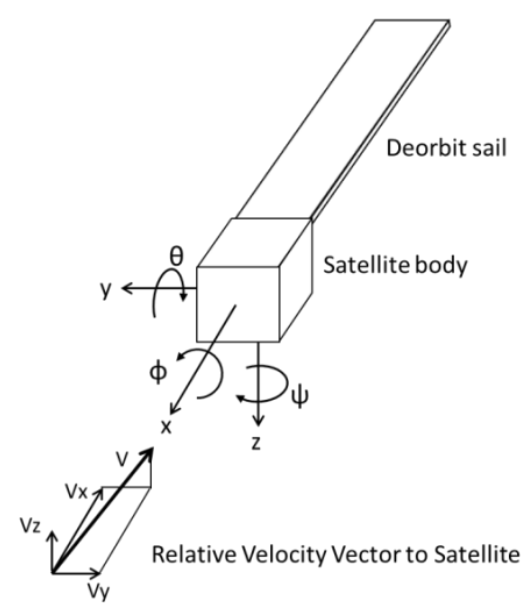

第 11 図 衛星モデルと相対速度の関係

$$
\begin{aligned}
& \mathrm{x} \text { 軸: }\left(C_{D}\right)_{\text {sat }-x}=\left(C_{D}\right)_{\text {cube }}+\left(C_{D}\right)_{\text {plate }-t} \cdot \frac{A_{\text {sail }}}{A_{\text {body }}} \\
& \mathrm{y} \text { 軸: }\left(C_{D}\right)_{\text {sat }-y}=\left(C_{D}\right)_{\text {cube }}+\left(C_{D}\right)_{\text {plate }-t} \cdot \frac{A_{\text {sail }}}{A_{\text {body }}} \\
& \mathrm{z} \text { 軸: }\left(C_{D}\right)_{\text {sat }-z}=\left(C_{D}\right)_{\text {cube }}+\left(C_{D}\right)_{\text {plate }-n} \cdot \frac{A_{\text {sail }}}{A_{\text {body }}}
\end{aligned}
$$

ここで, $\left(C_{D}\right)_{\text {cube }}$ は立方体の抵抗係数, $\left(C_{D}\right)_{\text {plate }-t}$ は平板 の気流方向の抵抗係数, $\left(C_{D}\right)_{\text {plate }-n}$ は平板の気流垂直方向 の抵抗係数, $A_{\text {body }}$ は衛星本体の正面面積, $A_{\text {sail }}$ はデオ 一ビットセイルの面積である. なお, 衛星全体の抵抗係数 $\left(C_{D}\right)_{\text {sat }}$ の基準面積は衛星本体の正面面積 $\left(A_{\text {body }}\right)$ とした.

式(6), (7), (8)による衛星の空気抵抗モデルは, 飛行速度 方向に対する衛星の姿勢に依存するため, 軌道上での衛星 の姿勢の変化を推定する必要がある. QSAT-EOS が軌道上 で姿勢制御を行った時の衛星の姿勢角速度センサ（FOG：

Fiber Optical Gyro）データの一例を第 12 図に示す。これは 地心指向制御の例であり, 指向制御開始と同時にアクチュ エータにより角加速度を発生させ, 一定角速度に達した後 にしばらくその状態を保持し，指向完了時点で角速度が零 となるように角加速度を発生させている，第 5 表には，衛 星の角速度が安定した区間における各軸まわりの角速度を 示す．各成分を合成した值は，約 $2.3^{\circ} / \mathrm{s}$ であった。

第 5 表 機体軸回り角速度 (QSAT-EOS FOG データ)

\begin{tabular}{|c|c|}
\hline $\mathrm{x}$ 軸回り (ロール) 角速度 & $-0.14\left({ }^{\circ} / \mathrm{s}\right)$ \\
\hline $\mathrm{y}$ 軸回り (ピッチ) 角速度 & $1.09\left({ }^{\circ} / \mathrm{s}\right)$ \\
\hline $\mathrm{z}$ 軸回り (ヨー) 角速度 & $-2.02\left({ }^{\circ} / \mathrm{s}\right)$ \\
\hline 合成值 & $2.30\left({ }^{\circ} / \mathrm{s}\right)$ \\
\hline
\end{tabular}

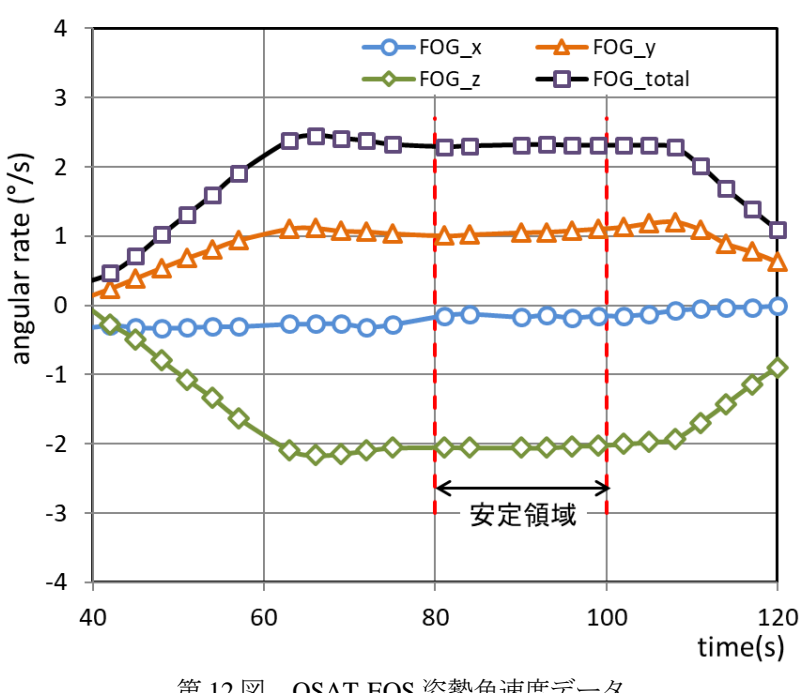

第 12 図 QSAT-EOS 姿勢角速度データ

式(6), (7), (8)で示すモデルを用いて, デオービットセイ ル展開量を $3 \mathrm{~m}$ (最大) とした時の衛星に働く空気抵抗力を 計算した結果の例を第 13 図(a)に示寸.これはピッチ軸回 りに $2.3^{\circ}$ /s の角速度を与えた場合の空気抵抗の履歴である.

一般的な衛星は, ミッション終了後に軌道離脱する段階 では積極的な姿勢制御はしないため, 衛星の気流に対する 姿勢はタンブリング運動により，時間と共に変化する。 そ こで，まず「QSAT-EOS」の初期角速度を用いて，各軸の 合成值が $2.3^{\circ}$ / $\mathrm{s}$ となるように, 初期角速度をランダムに与 えた．第 13 図(b)は空気抵抗の時間履歴の一例である.

デオービットセイルの影響は, ピッチ角が $90^{\circ}$ で気流に 垂直の姿勢が維持される場合に最大となる，そこで，姿勢 の回転によって空気抵抗が変化する場合の平均的効果を, 最大值に対する割合として評価した. その結果, 第 13 図(a) は最大值の約 60\%であり, 第 13 図(b)は約 $50 \%$ であった。

さらに, 角速度の合成值が $2.3 \%$ となるようなランダム な初期角速度を 20 とおり作成して, 最大值に対する割合と 平均抵抗值を計算した結果を第 14 図に示寸.衛星全体に働 く空気抵抗の平均值は, 衛星各軸まわりの角速度によらず, 第 13 図(b)の場合と同様に, 最大值の約 50\%であった.

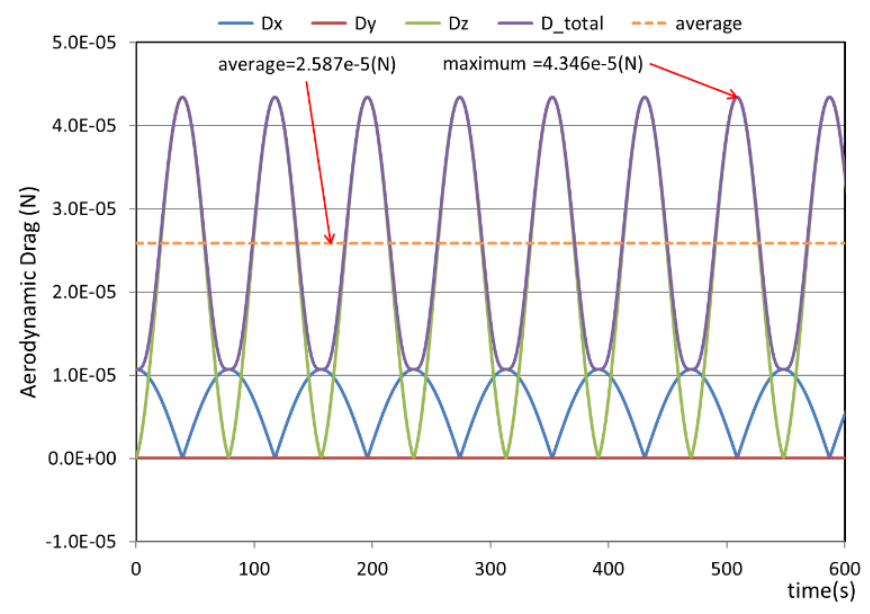

第 13 図(a) 衛星空気抵抗の計算例

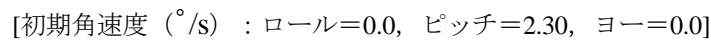




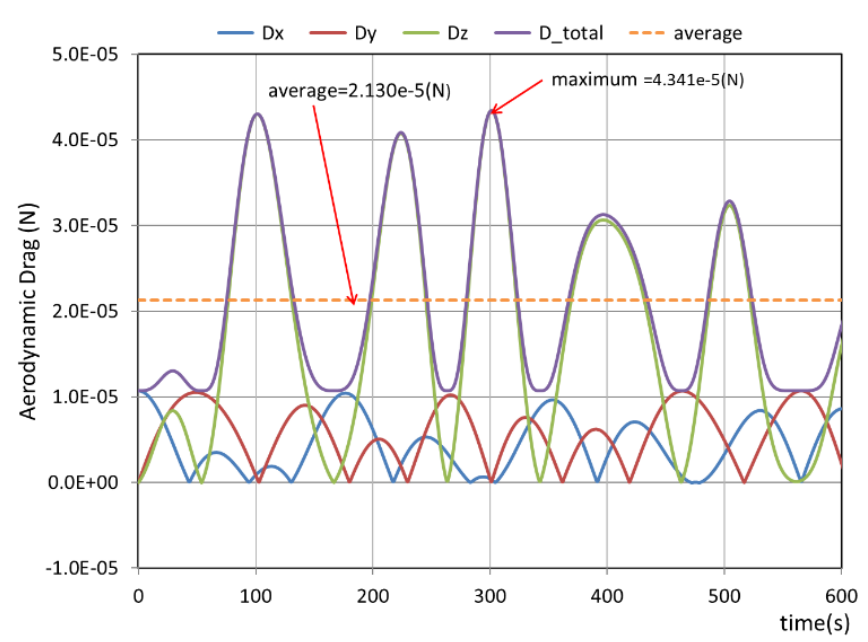

第 13 図(b) 衛星空気抵抗の計算例

[初期角速度 $(\% / \mathrm{s}) \quad$ : ロール $=0.32$, ピッチ $=0.95, \quad \exists ー=2.07]$

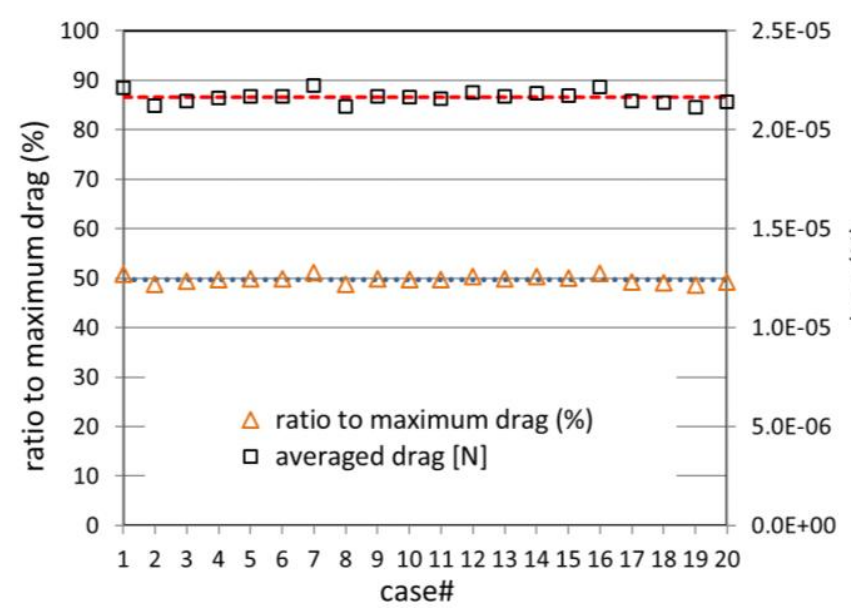

第 14 図 ランダムな角速度の場合の空気抵抗の平均值 デオービットセイル展開量 $=3.0 \mathrm{~m} ：$ 試行回数 20 回）

さらに, デオービットセイルの展開量をパラメータとし て同様の計算を実施した結果を第 15 図に示す.タンブリン グする衛星の空気抵抗值は, 最大值に対する比率がデオー ビットセイルの展開量によって変化することが分かる．こ れはデオービットセイルの展開量が少ない場合, 衛星がタ ンブリングしても気流に垂直方向の面積が大きく変化しな いので，衛星本体の抵抗值の寄与分が大きくなり，最大值 からの変化が少なくなるためであると考えられる.

さらに, 角速度が上記の空気抵抗值の最大值に対する比 率に与える影響を調べるために, 初期姿勢角速度を $2.0^{\circ} \%$, $3.0^{\circ} \mathrm{s}, 5.0^{\circ} \%$ と変化させて, 同様の計算を実施した。第 15 図には，初期角速度が $2.3 \%$ を含め 4 とおりの初期角速度 に対する計算結果も，右目盛りを用いて示している，いず れも, 平均值からの変動は非常に小さく, $0.2 \%$ 以下であっ た. 従って, 姿勢角速度が $5.0^{\circ} \mathrm{s}$ 程度の場合, 空気抵抗に 対する衛星の回転角速度の影響は微小であると考えられる.

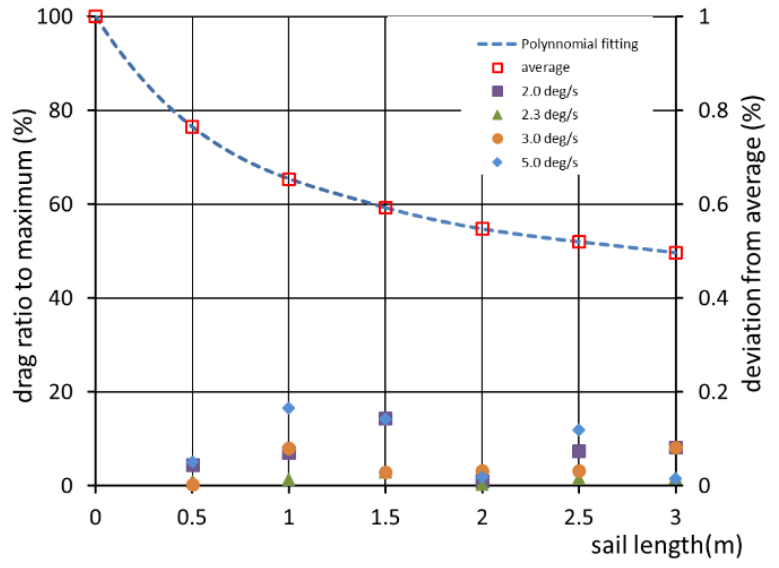

第 15 図 デオービットセイル展開量と空気抵抗（平均值）の関係 (衛星の初期角速度 $=2 \sim 5^{\circ} / \mathrm{s}$ の場合)

4. 3 シミュレーション結果 3 節の「ほじよし 1 号」の 解析で得られた修正係数（区間(1)：1.9, 区間(2): 2.8) 及び 2.4 節 (2)のデオービットセイルモデルを用いて, 「QSAT-EOS」の軌道を解析した。

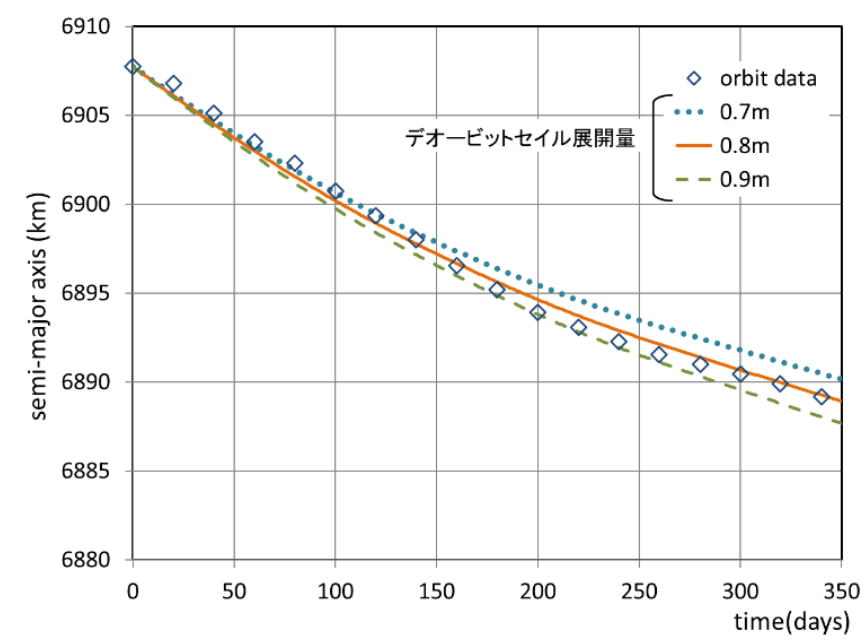

第 16 図(a) 半長径の変化「QSAT-EOS」（区間(1), 修正係数=1.9 )

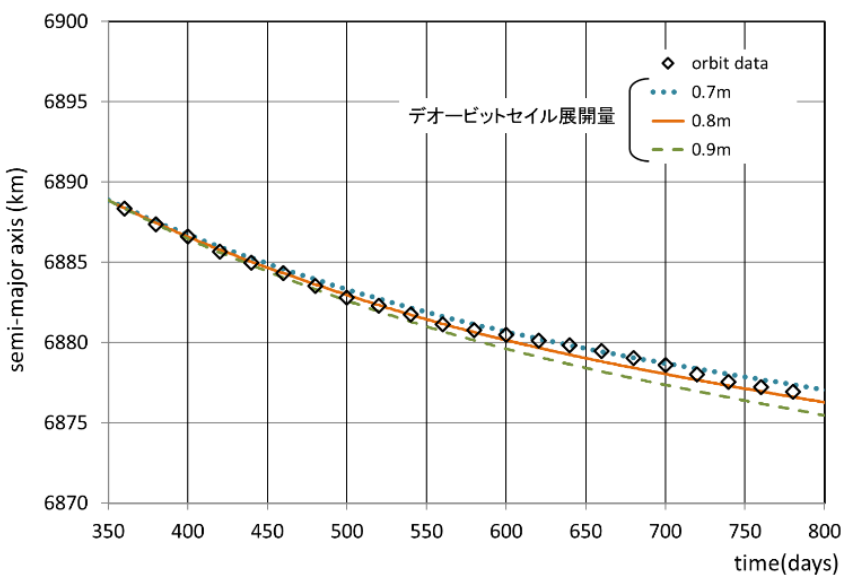

第 16 図(b) 半長径の変化「QSAT-EOS」（区間(2), 修正係数 $=2.8$ ) 
前述のとおり，デオービットセイルが部分的に展開して いる可能性があるため, デオービットセイルの展開量をパ ラメータとして変化させ, 軌道データと比較した. 結果を 第 16 図に示す. 図から分かるように, 区間(1)ではデオービ ットセイル展開量が $0.8 \mathrm{~m}$, 区間(2)ではデオービットセイル 展開量が $0.7 \sim 0.8 \mathrm{~m}$ の場合に軌道データと良い一致が得ら れた。この結果より，「ほどよし 1 号」の軌道データの解 析から得られた大気密度の修正係数は, 同時期の

「QSAT-EOS」にも有効であることが分かる.

さらに, 第 17 図にはデオービットセイルの展開量が $0.8 \mathrm{~m}$ の場合の区間(1)及び(2)全体を通した解析結果を示す.

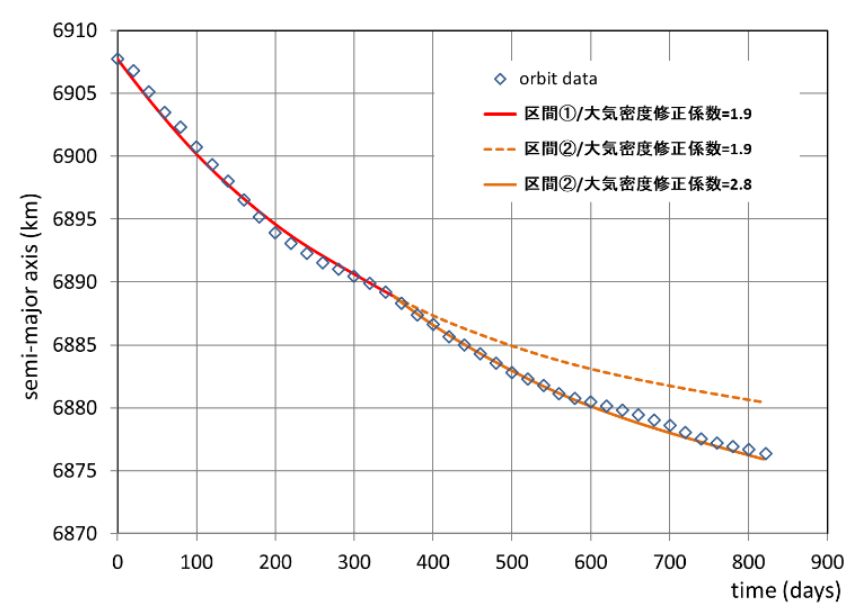

第 17 図 半長径の変化「QSAT-EOS」

(区間(1)(2)，デオービットセイル展開量 $=0.8 \mathrm{~m}$ )

第 7 図における「ほどよし 1 号」に対する解析では，大 気密度モデルの修正係数を区間(1)と区間(2)で変えることで， より実データに近い軌道高度の履歴が得られた. 第 17 図に は，区間(2における修正係数を区間(1)での值（1.9）を用い た結果も示している.これより，「QSAT-EOS」に対して も，2つの区間で異なる修正係数を用いた方が良い結果が 得られることが分かる.さらに，区間(2における修正係数 2.8 は Wertz モデルの大気密度の最大值を超えているが,

「QSAT-EOS」の解析で, デオービットセイルの展開量が が，区間(1)，区間(2)のいずれにおいても，約 $0.8 \mathrm{~m}$ という 結果が得られたことから, 実際の軌道上の大気密度が真值 に近かったのではないかということを示唆している。つま り，3 節の最後に記したように, 太陽黒点数が 60 個（F10.7 值が 100）を下回るような，太陽活動が弱い場合には，大 気密度が過小評価される可能性がある. そのため, 今後, モデルの精度を向上させる研究が望まれる.

\section{5. 結}

超小型衛星の運用終了後，新たなデブリの生成を抑制す るために, 運用後の衛星を大気に再突入させて廃棄する必 要があるが, 超小型衛星においては, 空気抵抗を利用する 展開式のデオービットセイルによる減速機構が有効と考え
られている．空気抵抗を利用する方式は，減速のためのエ ネルギー（スラスタ推力等）を必要としないため，ミッシ ヨン機器への質量配分の観点から有利であるが，大気突入 までの時間を管理することが難しいという課題がある．本 研究では空気抵抗を増加させるための展開式デオービット セイルのシミュレーションモデルを構築し，「ほどよし 1 号」及び「QSAT-EOS」の軌道上データにより，モデルの 妥当性を評価した。

(1) 立方体形状の「ほどよし 1 号」に対して Wertz のモデル を用いた解析を実施し, 軌道データとの比較により, Wertzのモデルの適用可能性を検討した. Wertzのモデル は太陽活動の影響を考慮しているが，解析と軌道データ との比較の結果, 太陽活動の変動を考慮するための修正 係数を導入することが必要であることが分かった.

設計時点における，空気抵抗による人工衛星の軌道高 度変化の推定に対する考え方は, その目的, 即ち, 軌道 上寿命（運用可能期間）の予測か，運用終了後の再投入 までの時間の予測かで異なる。運用期間は極力長く, 再 突入時間は極力短くなるように設計したいが，大気密度 の推定精度のリスクを考慮して設計余裕を設定すること が重要である．従って，一般的な衛星に対する軌道高度 変化の予測精度を向上させるためには, F10.7 值の変動を 考慮した修正係数の設定方法の確立は重要な課題であり, 多くの実軌道データを収集して修正係数の決定法につい て検討することが必要になる。

また，打ち上げ後の大気密度の予測精度を向上させる ことも有用であり, 打ち上げ後の軌道高度の変化から, 修正係数の精度を向上させることで, その衛星の将来の 軌道高度変化の精度を向上させることが期待できる.

(2) 立方体と平板のモデルを組み合わせたデオービットセ イル展開状態の衛星の空気抵抗モデルを構築した。この モデル及び太陽活動の影響を考慮した大気密度モデルを 用いることで，デオービットセイルを持つ衛星に対して も軌道高度を予測できることが分かった，また，本論文 で提示する手法により, 軌道高度データから, 逆にデオ ービットセイルの展開量を推定することも可能である.

以上のとおり, 人工衛星の軌道上寿命に大きく影響する 空気抵抗による減速に伴う軌道高度の低下を予測する手法 として, 運動方程式を積分するシミュレーションが有効で あることが確認された．ただし，軌道高度を低下させる空 気抵抗は大気密度モデルに大きく依存するため, 大気密度 の太陽活動による変動を考慮することが必要であり, デオ 一ビットセイル設計においては, 変動幅を考慮した余裕を 持たせることが望ましい. 
1) Inter-Agency Space Debris Coordination Committee: IADC Space Debris Mitigation Guidelines, IADC-02-01, 2002

2) Daniel Faber, Arthur Overlack, Willianne Welland, Laurens van Vliet, Wolter Wieling, and Flavia Tata Nardini: Nanosatellite Deorbit Motor, 27th Annual AIAA/USU, SSC13-I-9, 2013

3）大川 恭志，壹岐 賢太郎，奥村 哲平，松本 康司，岡本 博之，山 元 透, 河本 聡美: 導電性テザーシステムの実用化に向けた研究, 第 7 回「スペースデブリワークショップ」, JAXA-SP-16-011 E4, 2016

4) Nestor R. Voronka, Robert P. Hoty, Jeffrey T. Slostad, Ian Barnes, David Klumpar, Dylan Solomon, Doug Caldwell, and Rex Ridenoure: Technology Demonstrator of a Standardized Deorbit Module Designed for CubeSat and RocketPod Applications, 19th Annual AIAA/USU, SSC05-XI-4, 2005

5) Kevin Schillo, Christopher Valle, Kuo-Chi Lin, and Chan Ham: Analysis of the Performance Characteristics of a Gossamer Sail for Nanosatellite Applications, 25th Annual AIAA/USU SSC11-VIII-1 , 2011

6) E.G. Stansbery: Debris Assessment Software User's Guide, NASA/ TP-2016-218600-REV1

7) Howard D. Curtis: Orbital Mechanics for Engineering Students, $3 \mathrm{dr}$ Edition, Butterworth-Heinemann, ISBN-13:978-0-08-097747-8, 2014

8) 半揚稔雄: ミッション解析と軌道設計の基礎,現代数学社, ISBN978-4-7687-0439-4 , 2014

9) NOAA, NASA, US Air Force: U.S. Standard Atmosphere, 1976.

10) Daniel L. Oltrogge and Kyle Leveque: An Evaluation of CubeSat Orbital Decay , 25th Annual AIAA/USU, SSC11-VII-2, 2011

11) James R. Wertz, Nicola Sarzi-Amade, Anthony Shao, Christianna Taylor, and Richard E. Van Allen: Moderately Elliptical Very Low Orbits (MEVLOs) as a Long-Term Solution to Orbital Debris, $26^{\text {th }}$ Annual AIAA/USU Conference on Small Satellites, SSC12-IV-6, 2012

12) CelesTrack: Space Weather Data Documentation", https://celestrak.com/ SpaceData/SpaceWx-format.php

13) Sunspot Index and Long-term Solar Observations, Daily and monthly sunspot number (last 13 years), http://www.sidc.be/silso/dayssnplot

14) Richard Thompson: The Ten Centimetre Solar radio Flux, Space Weather Services, http://www.sws.bom.gov.au/Educational/2/2/5

15) NASA: Shape Effects on Drag, https://www.grc.nasa.gov/www/k-12/ airplane/shaped.html

16) A. Filippone: Aerodynamic Database, Drag Coefficients, https://web. archive.org/web/20070715171817/, http://aerodyn.org/Drag/tables.html ables.html 